\title{
PENGARUH ARUS KAS OPERASI, TINGKAT UTANG, DAN OPINI AUDIT TERHADAP PERSISTENSI LABA PADA PERUSAHAAN PERTAMBANGAN YANG TERDAFTAR DI BEI PERIODE 2013-2016
}

\author{
Amira Qurrata Aini ${ }^{1}$, Zuraida ${ }^{* 2}$ \\ ${ }^{1,2}$ Program Studi Akuntansi Fakultas Ekonomi dan Bisnis Universitas Syiah Kuala \\ e-mail: amiraqurrataaini@gmail.com¹, zuraidzuraida@unsyiah.ac.id ${ }^{2}$ \\ * Corresponding Author
}

\begin{abstract}
Abstrak
The study aims to determine the effect of operating cash flow, leverage, and audit opinions on earnings persistence. The population of this study is mining companies listed in Indonesian Stock Exchange in 2013-2016. The sample selected by purposive sampling method. The data used in this research is secondary data in the form of financial statement companies. Data analysis was performed using multiple linear regression statistical analysis. The results of this research show that operating cash flow, leverage, and audit opinions simultaneously influence earnings persistence. Partially operating cash flow and leverage significantly influence earnings persistence, whereas, audit opinions do not influence earning persistence.
\end{abstract}

Keywords: Earnings Persistence, Operating Cash Flow, Leverage, Audit Opinions

\section{Pendahuluan}

Setiap perusahaan mempunyai sasaran akhir untuk mendapatkan laba yang setinggi-tingginya (Kasmir, 2008:196). Informasi mengenai laba yang termuat di laporan laba rugi dan penghasilan komprehensif juga dimanfaatkan para pemakai laporan keuangan dalam memperkirakan bagaimana pencapaian arus kas dimasa mendatang dan memastikan profitabilitas, nilai investasi dan kelayakan kredit (Martani et al., 2016). Menurut Fanani (2010), jika dilihat berdasarkan aspek pihak manajemen, laba cenderung digunakan sebagai acuan dalam menarik minat para investor.

Laba merupakan salah satu elemen penting yang perlu diperhatikan didalam sebuah perusahaan. Subramanyam dan Wild (2013:144) memaparkan bahwa dalam menghitung tingkat kinerja perusahaan maka kualitas laba merujuk kepada relevansi laba, yang ditentukan dari kondisi usaha perusahaan dan penerapan dasar akuntansi yang ditetapkan serta diaplikasikan oleh perusahaan. Perusahaan terkadang mengalami perubahan tingkat penghasilan yang signifikan dari merugi hingga mendapatkan keuntungan dan pada lain waktu mengalami kerugian yang cenderung merosot tajam. Hal tersebut menyebabkan persistensi laba yang perusahaan miliki tidak berjalan lancar. Persistensi laba menurut Dewi dan Putri (2015) merupakan laba yang dapat menggambarkan keberlanjutan dari laba yang perusahaan miliki dalam rentang waktu yang panjang dimana laba tersebut tidak berfluktuasi.

Menurut Nuraini dan Purwanto (2014) investor yang cenderung memperhatikan besaran laba agregat, menghadapi fakta bahwa perusahaan memperoleh ataupun kehilangan sebagian besar labanya dalam waktu yang singkat. Fenomena yang terjadi antara lain adalah pada kasus PT Aneka Tambang (ANTM) yang mengalami kerugian pada awal semester 1-2017, dimana perusahaan mengalami kerugian yang disebabkan dari penurunan angka penjualan mencapai 27,66\% dengan nilai Rp 3,01 triliun. Depresiasi dan amortisasi aset yang dimiliki oleh perusahaan juga menjadi faktor penyebab terjadinya kerugian lainnya yang di alami oleh perusahaan. Perluasan Pabrik Feronikel Pomala (P3FP) adalah contoh bentuk depresiasi yang terjadi, sedangkan beban dari anak usaha perseroan yang ikut mempengaruhi kinerja keuangan perseroan yang menyebabkan amortisasi (Chandra, 2017).

Fenomena lainnya yakni kasus PT Bumi Resource Minerals (BMRS) yang menghadapi kerugian yang cukup drastis. Pada tahun 2015 
kerugian yang dialami sebesar US\$ 63,38 juta dan pada tahun 2016 dengan jumlah US\$ 458,98 juta atau setara dengan Rp 6,19 Ttriliun dengan kurs Rp 13.500. Penyebab utama terjadinya kerugian dikarenakan terjadi penurunan nilai aset perusahaan mencapai US\$ 660,26 juta (Astria, 2017).

Beberapa riset sebelumnya memperlihatkan bahwa arus kas operasi dapat mempengaruhi persistensi laba (Dewi dan Putri, 2015; Marnilin et al., 2015, Barus dan Rica, 2015; Rajizadeh dan Rajizadeh, 2017), tingkat utang (Nuraini dan Purwanto, 2014; Kasiono dan Fachrurrozie, 2016; Putri et al., 2017; Susilo dan Anggraeni, 2017), serta opini audit (Vichitsarawong dan Pornupatham, 2015).

Faktor pertama yang dapat berpengaruh terhadap persistensi laba berdasarkan studi terdahulu yaitu arus kas operasi. Menurut Putri et al., (2017) sumber kas yang perusahaan miliki dan gunakan diikhtisarkan pada laporan arus kas dalam rentang waktu tertentu. Asma (2013) memaparkan bahwa perusahaan tidak perlu mengandalkan pembiayaan dari pihak eksternal jika aktivitas operasi perusahaan tersebut cukup menghasilkan sumber aliran kas. Menurut Harrison et al., (2012:35) aktivitas operasi adalah aktivitas yang menciptakan pendapatan atau beban pada lini utama entitas bisnis. Terdapat lima komponen yang terlibat dalam aktivitas operasi yakni penelitian dan pengembangan, pembelian, produksi, pemasaran, dan administrasi (Subramanyam dan Wild (2013:22). Arus kas operasi yang terdapat pada perusahaan dapat berpengaruh positif terhadap persistensi laba (Dewi dan Putri, 2015). Hal ini bertolak belakang dengan Chowijaya et al., (2014) dan Saputera et al., (2017) yang menyatakan bahwa persistensi laba yang dimiliki tidak dipengaruhi oleh arus kas operasi perusahaan tersebut.

Faktor kedua terkait persistensi laba ialah tingkat utang. Tingkat utang dianggap bermanfaat dalam perusahaan dimana dapat mendukung situasi keuangan perusahaan dalam melakukan bisnis, akan tetapi jika utang yang dimiliki perusahaan terlalu besar dan bunga terlalu tinggi, tentu dapat mempengaruhi laba perusahaan. Menurut Fanani (2010) besarnya jumlah tingkat utang yang dimiliki perusahaan akan menaikkan persistensi laba, yang bertujuan memperlihatkan kemampuan perusahaan dalam mempertahankannya kepada pihak-pihak diluar perusahaan seperti, auditor dan investor. Hal yang sama yang ditunjukkan oleh hasil penelitian Kasiono dan Fachrurrozie (2016), dimana tingkat utang dapat memengaruhi persistensi laba. Hal ini berbeda dengan Suwandika dan Astika (2013) yang menyatakan bahwa tingkat utang tidak memiliki pengaruh terhadap persistensi laba.

Selain kedua variabel yang telah disebutkan, variabel lainnya yang memilki pengaruh terhadap persistensi laba ialah opini audit. Laporan audit merupakan sarana yang digunakan auditor dalam mengungkapkan kewajaran perihal laporan keuangan yang diaudit. Opini audit terdiri dari, Wajar Tanpa Pengecualian, Wajar Dengan Pengecualian, Tidak Wajar, dan Disclaimer. Opini audit berpengaruh terhadap persistensi laba, perusahaan yang memperoleh opini wajar tanpa pengecualian memiliki persistensi laba yang lebih baik, dibandingkan dengan perusahaan yang memiliki opini lainnya (Vichitsarawong dan Pornupatham, 2015). Berbeda dengan penelitian yang dilakukan Santana (2016) dan Moghaddam et al, (2016) yang menemukan hasil bahwa opini audit yang perusahaan peroleh tidak mempengaruhi persistensi laba.

Objek penelitian ini adalah perusahaan pertambangan yang terdaftar di BEI (Bursa Efek Indonesia). Berdasarkan hasil riset Pricewaterhouse Coopers $(P w C)$ pada tahun 2016, sebanyak 40 perusahaan tambang global mengalami kerugian terbesar selama 2015 yang disebabkan oleh harga komoditi yang anjlok, sehingga peneliti ingin melihat apakah kerugian tersebut berpengaruh terhadap perusahaan pertambangan di Indonesia (Ika, 2016).

Berdasarkan hasil penelitian terdahulu tentang persistensi laba terdapat research gap yang cukup signifikan dan tidak konsisten juga pentingnya melihat persistensi laba yang dimiliki perusahaan. Hal tersebut mendorong penelitian ini untuk dilaksanakan. Penelitian ini dilaksanakan dengan judul "Pengaruh Arus Kas Operasi, Tingkat Utang, dan Opini Audit terhadap Persistensi Laba pada Perusahaan Pertambangan yang terdaftar di BEI Periode 20132016".

\subsection{Kajian Pustaka}

\section{Teori Sinyal (Signaling Theory)}

Pasar dapat memprediksi bagaimana kondisi yang perusahaan alami, salah satunya dengan sinyal yang secara sengaja dilakukan oleh perusahaan jika 
memiliki kinerja baik. Menurut Hartono (2005), sinyal yang perusahaan miliki atas informasi yang dipublikasikan dapat mempengaruhi pertimbangan pengambilan keputusan. Penyampaian informasi keuangan perihal laba oleh pihak manejemen diharapkan mampu mempresentasikan sinyal kemakmuran terhadap pihak pemegang saham. Sinyal kemakmuran pada perusahaan dapat tercipta jika laba yang dimiliki cenderung tumbuh dan stabil (sustainable) yang informasinya terdapat didalam laporan laba (Marnilin et al., 2015).

Menurut Chowijaya et al., (2013), motivasi sinyal pada manajemen cenderung akan melaksanakan kebijakan akrual, yaitu manajemen akan memaparkan laporan laba yang dapat mencerminkan laba sesungguhnya untuk mengarahkan pada persistensi laba berdasarkan dorongan dari motivasi sinyal. Laba merupakan salah satu dari pertimbangan investor dalam hal memutuskan untuk berinvestasi atas kinerja yang dimiliki perusahan, jika pada sewaktu-waktu perusahaan yang mengalami kerugian dalam kurun waktu yang singkat dan dengan jumlah yang banyak tentu akan memberikan sinyal yang buruk kepada investor dan calon investor dalam menilai kinerja yang dimiliki perusahaan

\section{Persistensi Laba}

Laporan keuangan perusahaan memiliki tujuan sebagai sarana penyampaian informasi keuangan perihal tanggungjawab manajemen atas kinerja yang dicapai. Adapun Laba yang diperoleh atau rugi yang diderita suatu entitas dalam suatu periode usaha tertentu merupakan ukuran terpenting atas kinerja suatu entitas (Kartikahadi et al., 2012:180). Apabila manajemen melakukan tindakan yang tidak menggambarkan kondisi sebenarnya dalam hal melaporkan laba, hal ini tentu dapat mengindikasikan bahwa kualitas laba yang diperoleh diragukan (Novianti, 2012). Menurut Harrison et al., (2012:11), laba merupakan kenaikan manfaat ekonomi dalam suatu periode akuntansi seperti kenaikan aset atau penurunan kewajiban yang dapat meningkatkan ekuitas, kecuali transaksi dengan pemegang saham. Laba beserta komponen-komponennya adalah informasi penting yang dimanfaatkan oleh investor dan analisis keuangan dalam membuat keputusan (Rajizadeh \& Rajizadeh, 2013). Pihak-pihak yang memiliki kepentingan didalam perusahaan terkadang hanya memperhatikan laba berdasarkan dari peningkatan laba yang dihasilkan dan mengabaikan persistensi laba perusahaan selama kegiatan bisnis berjalan.

Terdapat dua sudut pandang yang berbeda dalam hal mengartikan persistensi laba perusahaan. Pandangan pertama mengartikan bahwasannya persistensi laba berkaitan dengan kinerja yang perusahaan miliki secara keseluruhan yang terjabarkan di dalam laba perusahaan, jika laba perusahaan persisten tinggi akan terefleksi pada laba dan dapat berkelanjutann untuk rentang waktu yang lama. Hal ini berbeda dengan pandangan yang lain menyatakan bahwa semakin kuat hubungan antara laba perusahaan dengan imbal hasil bagi investor dalam bentuk return saham dapat menunjukkan tingginya persistensi laba yang perusaaan miliki (Ayres, 1994; dalam Fanani, 2010).

Persistensi laba bisa dipergunakan untuk mengukur laba itu sendiri, dimana laba yang dihasilkan oleh perusahaan pada saat ini dipergunakan untuk indikator laba pada masa yang akan datang (Susilo dan Anggraeni, 2017). Jadi secara keseluruhan, persistensi laba merupakan harapan yang diinginkan oleh para pemegang saham (Nurochman dan Solikhah, 2015).

Pengukuran persistensi laba dalam penelitian ini digunakan rumus berikut sesuai pada pengukuran yang telah sebelumnya dilakukan oleh Suwandika dan Astika (2013), Dewi dan Putri (2015), Ariyani dan Wulandari (2018) yaitu:

\section{Laba sebelum pajak tahun depan}

$$
=\frac{\text { Laba sebelum pajak } t+1}{\text { Rata }- \text { rata total aset }}
$$

Keterangan:

Laba sebelum pajak $\mathrm{t}+1$ : Laba akuntansi sebelum pajak periode berikutnya

Rata-rata total aset : Total aset tahun yang diteliti ditambah dengan total aset tahun berikutnya dibagi dua

\section{Arus Kas Operasi}

Laporan arus kas merupakan laporan pada suatu rentang waktu tertentu yang digunakan dalam hal penginformasian arus kas masuk, arus kas keluar dan 
setara kas yang dimiliki perusahaan. Menurut Ariyani dan Wulandari (2018), ketika arus kas yang dimiliki oleh perusahaan berskala positif, maka akan memberikan kepercayaan perihal kemampuan perusahaan menghasilkan laba di periode mendatang. Arus kas terdiri atas aktivitas operasi, investasi, dan pendanaan (Surya, 2013:16). Arus kas dari aktivitas operasi melaporkan ikhtisar penerimaan dan pembayaran kas pada operasi perusahaan (Yadiati \& Wahyudi, 2006: 56)

Ruang lingkup operasi perusahaan tentu akan memengaruhi masalah keuangan yang dihadapi oleh suatu perusahaan (Sudana, 2011:10). Pada PSAK 2 paragraf 13 dinyatakan bahwasanya arus kas operasi terjadi berdasarkan kegiatan operasi perusahaan, yang dijadikan indikator dalam hal menentukan kemampuan perusahaan dalam memperoleh arus kas sebagai pembiayaan atas pinjaman modal, pemeliharaan kegiatan operasi perusahaan, pembayaran atas dividen, dan tidak menggunakan pendanaan diluar perusahaan untuk menginvestasi. Arus kas operasi masa depan diprediksi berdasarkan informasi unsur tertentu arus kas historis bersama dengan informasi lain (IAI, 2015).

Komponen aliran kas yang kian meningkat akan meningkatkan persistensi laba. Kondisi inilah yang membuat aliran kas operasi disebut sebagai proksi kualitas laba, semakin tingginya aliran kas operasi terhadap laba maka kualitas laba akan semakin baik (Dewi dan Putri, 2015).

Arus kas dari aktivitas operasi diperoleh dari aktivitas penghasil utama pendapatan perusahaan sehingga semakin tingginya aliran kas operasi terhadap laba maka akan semakin tinggi pula kualitas laba (Barus dan Rica, 2014),. Kepercayaan kemampuan perusahaan dalam mendapatkan laba pada periode mendatang cenderung dipengaruhi oleh keadaan arus kas dengan nilai positif (Putri et al., 2017)

Pengukuran arus kas operasi dalam penelitian ini mengikuti pengukuran yang dilakukan Marnilin et al., (2015), Dewi dan Putri (2015), Barus dan Rica (2014) berdasarkan total arus kas operasi pada tahun berjalan

$\mathrm{H}_{2}$ : Arus kas operasi berpengaruh positif terhadap persistensi laba

\subsubsection{Tingkat Utang}

Menurut Setiana (2012) pembagian utang terdiri dari utang jangka pendek yang periode peminjamannya dalam setahun maupun kurang dari setahun, dan utang jangka panjang yang pada praktiknya perusahaan menggunakannya untuk pengembangan usaha dalam kurun waktu cukup lama untuk mengembalikan modal. Perusahaan cenderung memiliki tingkat utang besar apabila perusahaan lebih banyak memiliki utang jangka panjang.

Menurut Susilo dan Anggraeni (2017), apabila utang yang dimiliki perusahaan naik, secara tidak langsung skala bisnis lebih meningkat. Hal ini dikarenakan adanya pertambahan modal dalam hal kegiatan operasi maupun pengembangan usaha. Perusahaan harus dapat memilih sumber pendanaan yang bertujuan memberikan keuntungan dan melebihi besarnya biaya aset (Romasari, 2013). Kasiono dan Fachrurrozie (2016) memaparkan bahwa banyaknya besaran tingkat utang terkait dengan arus masuk eksternal yang terkandung kegunaan ekonomi di masa mendatang, akan tetapi dari sisi lain, pelunasan utang pada saat jatuh tempo juga merupakan tanggung jawab perusahaan.

Penggunaan utang di dalam perusahaan menambah laba operasi yang lebih meningkat dari bunga yang dimilki, jika pencapaiannya berupa laba operasi lebih besar dan penggunaannya ditujukan salah satunya dengan persediaan yang dijual kembali (Putri et al., 2017).

Kasiono dan Fachrurrozie (2016) menjelaskan bahwa tingkat utang memengaruhi negatif persistensi laba perusahaan. Hal tersebut berbeda dengan Fanani (2010) yang menyatakan bahwa tingkat utang memengaruhi positif dan signifikan terhadap persistensi laba. Hal ini berarti semakin tinggi tingkat utang perusahaan maka perusahaan akan memliki laba yang lebih persisten.

Pengukuran tingkat utang mengikuti pengukuran sebelumnya oleh Kasiono dan Fachrurrozie (2016), Barus dan Rica (2014), dan Suwandika dan Astika (2013) dimana tingkat utang diukur dengan proksi rasio utang terhadap total aset (debt to total asset ratio).

Rasio utang terhadap total aset didapat dari membagi total utang perusahaan dengan total asetnya, yaitu: 


\section{Debt to Total Asset Ratio $=\frac{\text { Total Utang }}{\text { Total Aset }}$}

$\mathrm{H}_{3}$ : Tingkat utang berpengaruh terhadap persistensi laba

\section{Opini Audit}

Tujuan utama auditor ialah menyajikan pendapat perihal kewajaran laporan keuangan dengan prinsip-prinsip umum akuntansi (Subramanyam dan Wild, 2013:148). Opini Audit merupakan output dari prosedur-prosedur audit yang dilakukan oleh profesi akuntan publik (Purba, 2012:32). Perumusan opini yang dilakukan auditor berdasarkan pada evaluasi mengenai kesimpulan yang didapatkan dari bukti audit (Tuanakotta, 2013:507).

Rahayu dan Suhayati (2013:73) menyatakan bahwa laporan auditor adalah alat komukasi formal kepada pihak-pihak yang berkepentingan tentang apa yang telah dilakukan auditor dan kesimpulan yang dicapainya atas audit laporan keuangan. Santana (2016) juga menyatakan bahwa opini yang ditetapkan oleh auditor adalah berdasarkan dari pertimbangan dan analisa dengan cara profesional dan sesuai standar yang berlaku.

Pendapat yang dikeluarkan oleh auditor sangat membantu para investor maupun calon investor dalam membuat keputusan atas perusahaan, opini audit mempengaruhi persistensi laba apabila perusahaan diberikan opini WTP yang mempunyai persistensi laba lebih baik dibanding perusahaan dengan perolehan opini yang lain (Vichitsarawong dan Pornupatham, 2015).

Pengukuran opini audit menggunakan variabel dummy, Jika perusahaan mendapat opini WTP maka diberi kode 1, Jika perusahaan mendapat opini selain WTP diberi kode 0 .

$\mathrm{H}_{4}$ : Opini audit berpengaruh terhadap persistensi laba

\section{Metode Penelitian \\ Desain Penelitian}

Tujuan penelitian ini adalah untuk menguji variabel independen (arus kas operasi, tingkat utang, dan opini audit) terhadap variabel dependen (persistensi laba) dengan pengujian hipotesis.
Penelitian ini merupakan studi lapangan dengan intervensi minimal, dikarenakan tujuan penelitian ini menguji hipotesis maka diperlukan data yang sebenarnya yaitu melalui laporan keuangan perusahaan pertambangan yang terdaftar di website Bursa Efek Indonesia (BEI), Unit analisis yang digunakan yaitu perusahaan pertambangan yang terdaftar di BEI (Bursa Efek Indonesia). Data yang dikumpulkan berupa laporan keuangan seluruh perusahaan pertambangan di Indonesia dari tahun 2013-2016. Horizon waktu yang digunakan adalah pooled data (panel data), dimana studi ini memerlukan lebih dari satu tahap pengumpulan data pada waktu yang berbeda.

\section{Populasi dan Sampel Penelitian}

Populasi penelitian ini merupakan seluruh perusahaan pertambangan yang terdaftar secara berturut-turut di BEI pada tahun 2013-2016. Sampel dipilih menggunakan metode purposive sampling yaitu sampel yang memiliki kriteria-kriteria tertentu. Kriteria-kriteria tersebut antara lain:

1) Perusahaan pertambangan yang terdaftar di Bursa Efek Indonesia (BEI) dan tidak pernah de-list selama periode 2013-2016.

2) Perusahaan pertambangan yang menerbitkan laporan keuangan secara berturut-turut pada periode 2013-2016.

Berdasarkan kriteria tersebut, didapatkan sampel penelitian terdiri dari 33 perusahaan perusahaan pertambangan dengan jumlah awal observasi ialah 132 namun setelah dilakukan analisis, terdapat data tidak berdistribusi normal karena ditemukan 38 data outlier. sehingga data observasi yang awalnya berjumlah 132 setelah dikurangi 38 outlier, maka jumlah data observasi akhir yang dapat digunakan dalam penelitian ini ada 94 observasi.

\section{Sumber dan Teknik Pengumpulan Data}

Penelitian ini menggunakan data sekunder yaitu laporan keuangan perusahaan pertambangan yang terdaftar di BEI periode 2013-2016. Teknik pengumpulan data adalah teknik dokumentasi, dimana peneliti melakukan pengumpulan laporan keuangan tahunan yang terdapat di BEI. Pengumpulan data penelitian ini diperoleh dengan pengaksesan website Bursa Efek Indonesia (www.idx.co.id) untuk mendapatkan laporan keuangan. 


\section{Metode Analisis}

Metode analisis yang digunakan untuk menguji apakah variabel independen berpengaruh terhadap variabel dependen adalah analisis regresi linear berganda, persamaan regresi pada penelitian ini adalah:

$$
P L=a+b_{1} A K O+b_{2} T U+b_{3} O A+e
$$

Keterangan :

$\begin{array}{ll}\mathrm{PL} & : \text { Persistensi Laba } \\ \mathrm{a} & : \text { Konstanta } \\ \mathrm{b}_{1}, \mathrm{~b}_{2}, \mathrm{~b}_{3} & : \text { Koefisien Regresi } \\ \mathrm{AKO} & : \text { Arus Kas Operasi } \\ \mathrm{TU} & : \text { Tingkat Utang } \\ \mathrm{OA} & : \text { Opini Audit } \\ e & : \text { Epsilon (error term) }\end{array}$

\section{Hasil dan Pembahasan}

Hasil Penelitian

Deskripsi Objek Penelitian

Tujuan penelitian ini adalah untuk menguji pengaruh arus kas operasi, tingkat utang, dan opini audit terhadap persistensi laba pada perusahaan pertambangan yang terdaftar di BEI tahun 2013-2016. Objek penelitian dipilih menggunakan metode purposive sampling dengan menetapkan kriteriakriteria yang telah ditentukan. Berdasarkan kriteria tersebut diperoleh sampel sebanyak 94 perusahaan pertambangan yang terdaftar di BEI periode 20132016.

Analisis data dilakukan dengan menggunakan metode analisis regresi linear berganda. Langkah awal yang dilakukan adalah pengujian asumsi klasik antara lain uji normalitas, uji multikolinearitas, uji heteroskedastisitas dan uji autokoreasi. Kemudian, dilakukan uji hipotesis yaitu uji $t$ dan juga analisis regresi berganda dengan melihat nilai $\mathrm{t}$ dan nilai signifikan pada $0,05(5 \%)$.

Berdasarkan hasil uji asumsi klasik menunjukkan bahwa data penelitian normal dan bebas dari multikolinearitas, heteroskedastisitas maupun autokorelasi.

\section{Hasil Pengujian Regresi Linear Berganda}

\section{Tabel 1}

Hasil Regresi Linear Berganda

Coefficients $^{\mathbf{a}}$

\begin{tabular}{|l|r|r|r|r|r|r|r|}
\hline \multirow{3}{*}{ Model } & \multicolumn{2}{|c|}{$\begin{array}{c}\text { Unstandardized } \\
\text { Coefficients }\end{array}$} & \multicolumn{2}{c|}{$\begin{array}{c}\text { Standardized } \\
\text { Toefficients }\end{array}$} & \multirow{2}{*}{$\mathbf{t}$} & \multirow{2}{*}{ Sig. } & \multicolumn{2}{c|}{ Collinearity Statistics } \\
\cline { 2 - 4 } & \multicolumn{1}{c|}{ B } & Std. Error & $\boldsymbol{\beta}$ & & & Tolerance & \multicolumn{1}{c|}{ VIF } \\
\hline (Constant) &,- 449 &, 155 & & $-2,897$ &, 005 & & \\
Ln_AKO &, 018 &, 006 &, 315 & 3,236 &, 002 &, 993 & 1,007 \\
TU &,- 077 &, 037 &,- 208 & $-2,119$ &, 037 &, 973 & 1,027 \\
OA &, 061 &, 053 &, 112 & 1,142 &, 256 &, 977 & 1,024 \\
\hline
\end{tabular}

a. Dependent Variable: PL

Sumber: Output SPSS (2018)

Dari hasil perhitungan statistik dari tabel diatas, maka diperoleh persamaan regresi linear berganda sebagai berikut:

$$
P L=-0,449+0,018 X 1-0,077 \times 2+0,061 X 3+e
$$

Berdasarkan persamaan regresi tersebut dapat diketahui bahwa:

1) Konstanta $(\alpha)$ sebesar $-0,449$ artinya jika arus kas operasi, tingkat utang, dan opini audit dianggap sama dengan nol maka besarnya nilai persistensi laba sebesar $-44,9 \%$.

2) Koefisien regresi arus kas operasi sebesar 0,018 artinya setiap kenaikan nilai arus kas operasi sebesar $1 \%$ maka akan menaikkan persistensi laba perusahaan sebesar 1,8\% dengan asumsi variabel bebas lainnya konstan.

3) Koefisien regresi tingkat utang sebesar $-0,077$ dan bertanda negatif artinya setiap terjadi peningkatan nilai tingkat utang sebesar $1 \%$ maka akan menurunkan nilai persistensi laba 
sebesar 7,7\% dengan asumsi variabel bebas lainnya konstan.

4) Koefisien regresi opini audit sebesar 0,061 dan bertanda positif, artinya setiap kenaikan nilai sebesar $1 \%$ maka akan meningkatkan nilai persistensi laba sebesar $6,1 \%$ dengan asumsi variabel bebas lainnya konstan.

\section{Uji Statistik F}

Dilakukannya uji statistik F untuk melihat apakah Arus Kas Operasi, Tingkat Utang, dan Opini Audit berpengaruh secara bersama-sama terhadap Persistensi Laba

Tabel 2

Hasil Uji Statistik F

ANOVA ${ }^{b}$

\begin{tabular}{|l|c|c|c|c|c|}
\hline \multicolumn{1}{|c|}{ Model } & Sum of Squares & df & Mean Square & F & Sig. \\
\hline Regression &, 134 & 3 &, 045 & 5,497 &, $002^{\mathrm{a}}$ \\
Residual &, 730 & 90 &, 008 & & \\
Total &, 864 & 93 & & & \\
\hline
\end{tabular}

a. Predictors: (Constant), OA, Ln_AKO, TU

b. Dependent Variable: PL

Sumber: output SPSS (2018)

Nilai signifikansi yang didapatkan sebesar 0,002 dan lebih kecil dari taraf signifikan 0,05 (5\%), maka dapat disimpulkan bahwa $\mathrm{H}_{1}$ berhasil ditolak dan $\mathrm{Ha}_{1}$ diterima, sehingga variabel arus kas operasi, tingkat utang, dan opini audit secara simultan berpengaruh terhadap persistensi laba.

\section{Uji Statistik t}

Uji statistik $\mathrm{t}$ pada dasarnya menunjukkan seberapa jauh pengaruh variabel independen terhadap variabel dependen secara individual. Pengujian ini dilakukan untuk mengetahui seberapa besar pengaruh arus kas operasi, tingkat utang, danopini audit terhadap persistensi laba. Dasar keputusan yang diambil dengan melihat nilai signifikansi kurang dari 0,05 (5\%).

Tabel 3

Hasil Uji Statistik t

Coefficients $^{\mathbf{a}}$

\begin{tabular}{|l|c|c|c|c|c|c|c|}
\hline \multirow{2}{*}{ Model } & \multicolumn{2}{|c|}{$\begin{array}{c}\text { Unstandardized } \\
\text { Coefficients }\end{array}$} & $\begin{array}{c}\text { Standardized } \\
\text { Coefficients }\end{array}$ & \multirow{2}{*}{ T } & \multirow{2}{*}{ Sig. } & \multicolumn{2}{c|}{$\begin{array}{c}\text { Collinearity } \\
\text { Statistics }\end{array}$} \\
\cline { 2 - 5 } & $\mathbf{B}$ & Std. Error & $\boldsymbol{\beta}$ & & & Tolerance & VIF \\
\hline (Constant) &,- 449 &, 155 & & $-2,897$ &, 005 & & \\
Ln_AKO &, 018 &, 006 &, 315 & 3,236 &, 002 &, 993 & 1,007 \\
TU &,- 077 &, 037 &,- 208 & $-2,119$ &, 037 &, 973 & 1,027 \\
OA &, 061 &, 053 &, 112 & 1,142 &, 256 &, 977 & 1,024 \\
\hline
\end{tabular}

a. Dependent Variable: PL

Sumber: Output SPSS (2018)

Berdasarkan Tabel diatas, dapat disimpulkan bahwa:

1. Variabel arus kas operasi memiliki nilai signifikansi 0,002 lebih kecil dari 0,05 (5\%), dengan demikian, $\mathrm{HO}_{2}$ ditolak dan $\mathrm{Ha}_{2}$ diterima. Hal ini menunjukkan bahwa arus kas operasi berpengaruh terhadap persistensi laba.

2. Variabel tingkat utang memiliki nilai signifikansi 0,037 lebih kecil dari 0,05 (5\%) dengan demikian $\mathrm{HO}_{3}$ ditolak dan $\mathrm{Ha}_{3}$ diterima. Hal ini menunjukkan bahwa tingkat utang berpengaruh terhadap persistensi laba.

3. Variabel opini audit memiliki nilai signifikansi 0,256 lebih besar dari $0,05(5 \%)$ sehingga $\mathrm{HO}_{4}$ tidak berhasil ditolak dan $\mathrm{Ha}_{4}$ ditolak Hal ini menunjukkan bahwa opini audit tidak berpengaruh secara signifikan terhadap persistensi laba. 


\section{Uji Koefisien Determinasi $\left(\mathbf{R}^{2}\right)$}

Uji koefisien determinasi pada penelitian ini bertujuan untuk mengukur sejauh mana kemampuan model dalam menerangkan variasi variabel dependen. Nilai koefisien determinasi berada diantara nol dan satu.

\section{Tabel 4}

Hasil Uji Koefisien Determinasi

Model Summary ${ }^{b}$

\begin{tabular}{|c|r|r|r|r|r|}
\hline Model & R & R Square & Adjusted R Square & Std. Error of the Estimate & Durbin-Watson \\
\hline 1 &, $394^{\mathrm{a}}$ &, 155 &, 127 &, 090064 & 1,827 \\
\hline
\end{tabular}

a. Predictors: (Constant),OA, Ln_AKO, TU

b. Dependent Variable: PL

Sumber: output SPSS (2018)

Nilai $\mathrm{R}^{2}$ sebesar 0,155 atau sebesar $15,5 \%$. Hal ini menunjukkan bahwa 15,5 \% variabel dependen (Persistensi laba) dapat dijelaskan oleh ketiga variabel independen dalam penelitian ini yaitu arus kas operasi, tingkat utang, dan opini audit, sedangkan 84,5\% lainnya dijelaskan oleh variabel lain yang tidak dimasukkan dalam penelitian ini.

\section{Pembahasan Hasil Pengujian Hipotesis Pengaruh Arus Kas Operasi terhadap Persistesni Laba}

Berdasarkan uji t yang dilakukan variabel arus kas operasi memiliki nilai t sebesar 3,236 dengan tingkat signifikansi 0,002 lebih kecil dari 0,05 (5\%) yang berarti bahwa $\mathrm{HO}_{2}$ ditolak dan $\mathrm{Ha}_{2}$ diterima yang menunjukkan bahwasannya arus kas operasi dapat berpengaruh secara positif terhadap persistensi laba. Arus kas operasi yang tinggi akan membuat persistensi laba semakin meningkat. Sejalan dengan penelitian yang dilakukan oleh Dewi dan Putri (2015), Marnilin et al. (2015), Barus dan Rica (2015) serta Rajizadeh dan Rajizadeh (2017), yang menunjukkan hasil bahwa arus kas operasi berpengaruh positif terhadap persistensi laba.

Arus kas operasi yang perusahaan miliki merupakan informasi kinerja keuangan yang berguna dalam menilai potensi yang dimiliki perusahaan dan dapat dijadikan sebagai indikator untuk mengukur kesuksesan kinerja perusahaan. Menurut Marnilin et al. (2015), jika indikator keuangan berdasarkan data arus kas relatif maka akan lebih sulit dimanipulasi sehingga baik untuk digunakan. Persistensi laba dapat dipengaruhi arus kas operasi, operasional perusahaan yang baik dapat menghasilkan laba yang baik dan dapat digunakan kembali pada kegiatan operasi perusahaan dengan tidak memakai modal maupun utang dengan pihak lain (Salsabiila et al., 2016).

Hasil penelitian ini sejalan dengan Teori Signaling yang menyatakan bahwa jika perusahaan memiliki persistensi laba yang tinggi dan tingkat arus kas operasi perusahaan yang tinggi merupakan suatu berita baik yang akan memberikan sinyal positif bagi pasar. Hal ini mengindikasikan keberhasilan perusahaan dalam menjaga kestabilan laba.

Namun demikian, hasil ini tidak sejalan dengan penelitian sebelumnya yang dilakukan oleh Chowijaya et al., (2014) dan Saputera et al., (2017) yang menyatakan bahwa arus kas operasi tidak berpengaruh terhadap persistensi laba.

\section{Pengaruh Tingkat Utang Terhadap Persistensi Laba}

Hasil penelitian ini mendapatkan variabel tingkat utang berpengaruh negatif terhadap persistensi laba, berdasarkan uji t yang dilakukan variabel tingkat utang memiliki memiliki nilai t sebesar -2,119 dengan tingkat signifikansi signifikansi 0,037 lebih kecil dari $0,05(5 \%)$ sehingga $\mathrm{HO}_{3}$ ditolak dan $\mathrm{Ha}_{3}$ diterima. Hasil tersebut sejalan dengan penelitian yang dilakukan Kasiono dan Fachrurrozie (2016) serta Sari (2018).

Hubungan negatif yang ditujukan yaitu perusahan dengan jumlah utang yang besar tentu akan memberikan risiko yang cukup besar juga terhadap kelansungan kegiatan perusahaan yang dapat mempengaruhi persistensi laba. Kasiono dan Fachrurrozie (2016) juga menemukan adanya pengaruh negatif tingkat utang terhadap persistensi laba dimana sebuah perusahaan akan mengalami penurunan tingkat kestabilan persistensi laba jika 
memiliki tingkat utang yang dalam jumlah besar akan berdampak pada perusahaan.

Hasil penelitian ini tidak sejalan dengan penelitian Suwandika dan Astika (2013), Barus dan Rica (2014), serta Nurochman dan Solikhah (2015)yang berpendapat bahwa tingkat utang tidak berpengaruh terhadap persistensi laba. Menurut Barus dan Rica (2014), risiko perusahaan timbul jika pada saat jatuh tempo tidak mampu membayar sehingga terjadi kegagalan. Risiko juga dapat terjadi ketika perusahaan berusaha terus menerus menutupi utang dan bunga dengan menggunakan laba yang diperoleh perusahaan dan tidak memperhatikan pemeliharaan penghasilan perusahaan dan pembiayaan kegiatan operasional perusahaan. Hal tersebut akan mempengaruhi terjadinya penurunan laba dimasa yang akan datang.

\section{Pengaruh Opini Audit Terhadap Persistensi Laba}

Opini audit tidak berpengaruh secara signifikan terhadap persistensi laba di dalam penelitian ini, berdasarkan uji t yang dilakukan opini audit memiliki nilai t sebesar 1,142 dengan tingkat signifikansi 0,256 lebih besar dari 0,05 (5\%) sehingga $\mathrm{H}_{4}$ tidak berhasil ditolak dan $\mathrm{Ha}_{4}$ ditolak. Hasil ini didukung dengan penelitian yang dilakukan Santana (2016), dan Moghaddam et al., (2016) yang menyatakan bahwa opini audit tidak berpengaruh terhadap persistensi laba.

Menurut Moghaddam et al. (2016), opini audit tidak berpengaruh pada persistensi laba karena opini audit yang diperoleh suatu perusahaan, tidak dapat mempresentasikan persistensi laba yang dimiliki serta kualitas laba perusahaan. Tujuan dilakukannya audit atas laporan keuangan ialah mengukur apakah laporan yang perusahaan miliki telah wajar dan sesuai dengan ketenetuan dan standar akuntansi sehingga opini audit tidak bertujuan menilai bagaimana perusahaan memiliki kemampuan dalam hal menghasilkan laba yang persisten (Santana, 2016).

Hasil penelitian ini berbeda dengan pernyataan Vichitsarawong dan Pornupatham (2015) dimana opini audit berpengaruh terhadap persistensi laba, perusahaan yang memperoleh opini audit wajar tanpa pengecualian memiliki laba yang lebih persisten dibandingkan dengan perusahaan yang memperoleh opini audit selain wajar tanpa pengecualian.

\section{Kesimpulan, Keterbatasan dan Saran Kesimpulan}

Kesimpulan dari hasil penelitian ini adalah :

1) Arus kas operasi, tingkat utang, dan opini audit secara bersama-sama berpengaruh signifikan terhadap persistensi laba pada perusahaan pertambangan yang terdaftar di BEI periode 2013-2016.

2) Arus kas operasi berpengaruh signifikan terhadap persistensi laba pada perusahaan pertambangan yang terdaftar di BEI periode 2013-2016

3) Tingkat utang berpengaruh signifikan terhadap persistensi laba pada perusahaan pertambangan yang terdaftar di BEI periode 2013-2016.

4) Opini audit tidak berpengaruh secara signifikan terhadap persistensi laba pada perusahaan pertambangan yang terdaftar di BEI periode 2013-2016.

\section{Keterbatasan Penelitian}

Keterbatasan pada penelitian ini diharapkan dapat digunakan sebagai masukan pada penelitian selanjutnya agar diperoleh hasil yang lebih baik lagi, antara lain:

1) Penelitian ini hanya mengkhususkan pada perusahaan pertambangan yang terdaftar di BEI, serta periode pengamatan penelitian hanya empat tahun yaitu tahun 2013-2016 yang berdampak pada sedikitnya total sampel pada penelitian.

2) Nilai $R^{2}$ pada penelitian hanya $15,5 \%$, artinya masih banyak terdapat variabel bebas lain yang dapat memengaruhi persistensi laba yang tidak dimasukkan dalam penelitian ini.

\section{Saran}

Berdasarkan hasil analisis, pembahasan, kesimpulan, dan keterbatasan pada penelitian ini, saran-saran yang dapat diberikan antara lain:

\section{Saran A kademis}

1) Penelitian lanjutan diharapkan tidak hanya menggunakan perusahaan pertambangan, namun pada subjek yang lebih luas, seperti seluruh perusahaan yang terdaftar di BEI agar mendapatkan hasil yang lebih kompleks. Pada 
penelitian selanjutnya rentang waktu periode penelitian dapat ditambahkan.

2) Diharapkan adanya penambahan variabel bebas lain yang relevan dan diduga dapat memengaruhi persistensi laba yang tidak terdapat pada penelitian ini.

\section{Saran Praktis}

1) Perusahaan harus dapat memperhatikan kestabilan laba yang dimiliki agar menjadi pengukur kinerja perusahaan.

2) Bagi investor sebaiknya dapat lebih memperhatikan keputusan investasi tidak hanya pada sisi kenaikan laba namun pada persistensi laba yang dimiliki sebuah perusahaan

\section{Daftar Pustaka}

Ariyani, D., \& Wulandari, R. (2018). Pengaruh book tax differences dan arus kas terhadap persistensi laba (studi empiris pada perusahaan manufaktur yang terdaftar di BEI). Jurnal Universitas Pamulang, 2(2), 563-574.

Asma, T. N. (2013). Pengaruh aliran kas dan perbedaan antara laba akuntansi dengan laba fiskal terhadap persistensi laba. Skripsi. Padang: Program Sarjana: Universitas Negri Padang

Astria, R. (2017). Rugi bumi resource minerals BRMS membengkak.

melalui (Https://Market.bisnis.com). Diakses tanggal 11 Maret 2018.

Barus, A. C., \& Rica, V. (2014). Analisis faktor-faktor yang mempengaruhi persistensi laba pada perusahaan manufaktur di bursa efek indonesia. Jurnal Wira Ekonomi Mikroskil, 4(2), 71-80.

Chandra, A. A. (2017). Antam rugi Rp 496 miliar di semester 1-2017. Melalui (Https://Finance.Detik.Com). Diakses tanggal 16 Maret 2018.

Chowijaya, A., Effendi, R., \& Wenny, C. D. (2013). Pengaruh laba akuntansi, laba fiskal, dan arus kas operasi terhadap persistensi laba ( studi empiris pada industri yang tergabung di indeks LQ-45 ). Jurnal STIE MDP, 1-12.

Dewi, N. P. L., \& Putri, I. A. D. (2015). Pengaruh book-tax difference, arus kas operasi, arus kas akrual, dan ukuran perusahaan pada persistensi laba. E-Jurnal Akuntansi Universitas Udayana, 10.(1),244-260.

Fanani, Z. (2010). Analisis faktor-faktor penentu persistensi laba. Jurnal Akuntansi Dan Keuangan Indonesia, 7(1), 109-123.

Ghozali, I. (2013). Aplikasi analisis multivariat dengan program IBM SPSS 21

(Edisi Ketujuh). Semarang: Universitas Diponegoro.

Hartono, J (2005). Hubungan teori signalling dengan underpricing saham perdana di Bursa Efek Jakarta. Jurnal Bisnis Dan Manajemen, 5, $35-50$

Harrison, W. T., Horngreen, C. T., Thomas, B., dan Suwardy, R. (2012). Akuntansi Keuangan. Jakarta: Erlangga.

IAI. (2015). Standar Akuntansi Keuangan. Jakarta: Salemba Empat.

Ika, A. (2016). PwC: 40 perusahaan tambang dunia alami kerugian sekitar Rp.364.5 triliun. Melalui (Https:Ekonomi.Kompas.com). Diakses tanggal 11 Maret 2018.

Kasiono, D., \& Fachrurrozie, F. (2016). Determinan persistensi laba padaperusahaan manufaktur yang terdaftar di BEI. Accounting Analysis Journal, 5(1), 1-8.

Kartikahadi, H., Sinaga, R.U., Syamsul, M., \& Siregar, S V., (2012). Akuntansi Keuangan berdasarkan SAK berbasis IFRS. Jakarta: Salemba Empat

Kasmir. (2008). Analisis laporan keuangan. (Edisi Kesatu.). Jakarta: Rajagrafindo Persada.

Marnilin, F., Mulyadi, J., \& Darmansyah. (2015). Analisis determinan terhadap persistensi laba pada perusahaan jasa di BEI. Media Riset Akuntansi. Auditing Dan Informasi, 15(1), 89-102.

Martani, D., Siregar, S. V., Wardani, R., Farahmita, A., \& Tanujaya, E. (2016). Akuntansi Keuangan Menengah Berbasis PSAK (Edisi Kedua). Jakarta: Salemba Empat.

Meythi. (2006). Pengaruh arus kas operasi terhadap harga saham dengan persistensi laba sebagai variabel intervening. Simposium Nasional Akuntansi 9 Padang, 1-24.

Moghaddam, A. G., Pakdelan, S., Zeinabi, S. N., Valiei, E., \& Rahiminezhad, S. (2016). Investigating the relationship between audit opinions and earning management in the companies listed in Tehran Stock Exchange. Asian Journal of Research in Banking and Finance, 4(2), 48-59.

Novianti, R. (2012). Kajian kualitas laba pada perusahaan manufaktur yang terdaftar di BEI. Accounting Analysis Journal, 1(2), 1-6

Nuraini, M., \& Purwanto, A. (2014). Analisis faktorfaktor penentu persistensi laba. E-Journal Undip, 3(3). 
Nurochman, A., \& Solikhah, B. (2015). Pengaruh good corporate governance, tingkat hutang dan ukuran perusahaan terhadap persistensi laba. Accounting Analysis Journal, 4(4), 1-9.

Purba, M. P. (2012). Profesi akuntan publik di Indonesia. Yogyakarta: Graha Ilmu

Putri, S. A., Khairunnisa, \& Kurnia. (2017). Pengaruh aliran kas operasi, book tax differences, dan tingkat hutang terhadap persistensi laba. Jurnal Riset Akuntansi Kontemporer , 9(1), 20-35.

Rahayu, S. Kurnia, \& Suhayati, E. (2013). Auditing konsep dasar dan pedoman pemeriksaan akuntan publik. Yogyakarta: Graha Ilmu.

Rajizadeh, S., \& Rajizadeh, S. (2013). Examining the factors affecting earnings persistency among the listed firms in tehran stock exchange. European Online Joural of Natural and Social Science, 2(3), 2073-2079.

Romasari, S. (2013). Pengaruh persistensi laba, struktur modal, ukuran perusahaan dan alokasi pajak antar periode terhadap kualitas laba (studi empiris pada perusahaan manufaktur yang terdaftar di BEI). Jurnal Akuntansi, 1(2), 1-21

Salsabiila, A. S., Pratomo, D., \& Nurbaiti, A. (2016). Pengaruh book tax differences dan aliran kas operasi terhadap persistensi laba. Jurnal Akuntansi, 20(2), 314-329.

Santana, R. P. (2016). Analisis pengaruh opini audit dan komite audit terhadap persistensi laba. Fakultas Ekonomika dan Bisnis. Skripsi. Semarang: Program Sarjana Universitas Diponegoro.

Saputera, E. N., Norita, \& Dillak, V. J. (2017). Pengaruh book tax differences dan aliran kas operasi terhadap persistensi laba (studi pada perusahaan pertambangan sektor batubara yang terdaftar di BEI Tahun 2011-2015). e-Proceeding of Management, 4(1), 523-532.

Sekaran, U., \& Bougie, R. (2017). Metode penelitian untuk bisnis (Edisi Keenam). Jakarta: Salemba Empat.

Setiana, E. (2012). Analisis pengaruh struktur modal terhadap kinerja pada perusahaan otomotif yang terdaftar di BEI tahun 2008-2010. Jurnal Telaah Akuntansi, 13(01), 33-50.

Subramanyam, K. R., \& Wild, J. J. (2013). Analisis laporan keuangan (Edisi Kesepuluh). Jakarta: Salemba Empat.

Sudana, I. M. (2011) Manajemen keuangan perusahaan teori \& praktik. Jakarta: Erlangga.

Surya, R. A. S. (2012). Akuntansi Keuangan versis IFRS, (Edisi Kesatu.). Yogyakarta: Graha
Ilmu.

Surya, R. A. S. (2013). Pengantar akuntansi berbasis IFRS (Edisi Kesatu.) Yogyakarta: Graha Ilmu.

Susilo, T. P., \& Anggraeni, B. M. (2017). Pengaruh volatilitas arus kas, tingkat utang, siklus operasi, dan ukuran perusahaan terhadap persistensi laba. Media Riset Akuntansi, 6(1), 4-21.

Suwandika, I. M. A., \& Astika, I. B. P. (2013). Pengaruh perbedaan laba akuntansi, laba fiskal, tingkat hutang pada persistensi laba. E-Jurnal Akuntansi Universitas Udayana, 5(1), 196-214.

Tuanakotta, T. M. (2013). Audit berbasis ISA. Jakarta: Salemba Empat.

Vichitsarawong, T., \& Pornupatham, S. (2015). Do audit opinions reflect earnings persistence? Managerial Auditing Journal, 30(3), 244-2.

Yadiati, W., \& Wahyudi, I. (2006). Pengantar akuntansi. Jakarta: Kencana 